\title{
PENDEKATAN PSIKOLOGIS DALAM UPAYA MENGATASI KECANDUAN PENYALAHGUNAAN NARKOTIKA
}

\author{
Rois Nafi'ul Umam \\ Rnafiul@gmail.com \\ Sutya Dewi \\ Sutyadewi65@gmail.com \\ Intan Belinda Cahyana \\ intanbelinda65@gmail.com \\ Miftahul Jannah \\ miftahuljannahmif6@gmail.com \\ UIN Sunan Kalijaga Yogyakarta
}

\begin{abstract}
Happiness and serenity in living life is the hope of every individual, to achieve this there are many things that can be done, one of which is like increasing worship to Allah, but not all individuals have the same thoughts, there are individuals who choose to achieve happiness and tranquility by abusing it. illegal drugs such as narcotics. The purpose of this study was to describe the role of a psychological approach as an effort to overcome addiction for narcotics abusers. The method used in this research is a qualitative method with a literature study approach by tracing and reviewing several documents in the form of journals and books. From the analysis carried out, the psychological approach plays a role in rehabilitating narcotics abusers through the activity of reading the Koran, prayer therapy and giving tausiah.
\end{abstract}

Keywords: Narcotics, psychological approach, narcotics abuse

\section{Pendahuluan}

Kebahagiaan dan ketenangan dalam menjalani hidup merupakan harapan yang hendak dicapai oleh setiap individu. Untuk dapat memperoleh hal tersebut, banyak hal-hal yang biasa dilakukan, seperti dalam agama Islam dianjurkan untuk memperbanyak beribadah kepadanya. ${ }^{1}$ Cara lain yang digunakan adalah menyalurkan hobby, pergi ke tempat yang disenangi dan melakukan berbagai aktivitas yang menarik. Akan tetapi tidak semua individu memiliki pemikiran untuk mencapai ketenangan hidupnya dengan cara tersebut. Mereka memilih untuk

\footnotetext{
${ }^{1}$ Khairul Hamim, 'Kebahagiaan dalam Perspektif Alquran dan Filsafat', Jurnal Tasamuh, 13.2 , (2016), hlm 127149.
} 
mencapai ketenangan dengan cara menyalahgunakan narkotika dan obat-obatan terlarang. ${ }^{2}$

Narkotika merupakan sejenis zat yang berasal dari tanaman maupun non tanaman, baik yang bersifat sintetis maupun non sintetis yang dapat menyebabkan penurunan atau perubahan pada tingkat kesadaran individu. ${ }^{3}$ Zat ini dapat bersifat adiksi yang menyebabkan individu menjadi ketergantungan akan penggunaan obatobatan terlarang tersebut. ${ }^{4}$ Penyalahgunaan narkotika yang menimbulkan efek "fly" atau hilang kesadaran ini yang dicari oleh para penggunanya agar dirinya merasa lebih tenang dan terbebas dari segala masalah yang menghampirinya.

Penyalahgunaan narkotika yang dilakukan baik jangka pendek maupun jangka panjang dapat berdampak buruk pada kesehatan secara fisik maupun psikis para pemakainya. Dampak negatif secara fisik yang ditimbulkan adalah gangguan pada sistem syaraf, jantung, pembuluh darah, dan adanya potensi penularan hepatitis B,C dan HIV karena penggunaan jarum suntik yang digunakan secara bersamaan. ${ }^{5}$ Adapun dampak secara psikis yang ditimbulkan adalah bersikap agresif, sering gelisah, hilangnya kepercayaan diri, dan sulit berkonsentrasi. ${ }^{6}$

Masalah penyalahgunaan narkotika sebagaimana yang telah dipaparkan diatas, perlu diselesaikan agar para penyalahguna tersebut tidak semakin terjerumus kedalam hal-hal yang negatif, baik secara fisik maupun psikis. Salah satu pendekatan yang dapat digunakan adalah melalui pendekatan psikologis. Layanan rehabilitasi dengan menggunakan pendekatan psikologis akan melihat kondisi kejiwaan dari klien dan melakukan terapi dengan metode-metode yang bersentuhan dengan ajaran Islam. ${ }^{7}$ Melalui pendekatan psikologis dalam rehabilitasi ini, diharapkan dapat membentuk kembali pribadi yang sehat secara

\footnotetext{
2 Rusmalena, dkk, 'Persepsi Masyarakat Terhadap Pengguna Narkoba di Tanjung Pinang Kota' Jurnal Sosiologis, 6.4, (2014), hlm.1-13

${ }^{3}$ Istiani Heriani, 'Upaya Penanggulangan Penyalahgunaan Narkoba Secara Komprehensif' Jurnal Al-‘Adl, 6.1l, (2014), hlm. 44-59

${ }^{4}$ Istiani Heriani, 'Upaya Penanggulangan Penyalahgunaan Narkoba Secara Komprehensif' Jurnal Al-'Adl, 6.1l, (2014), hlm 44-59

${ }^{5}$ Harbia, 'Dampak Penyalahgunaan Narkotika, Psikotropika dan Zat Adiktif lainnya terhadap seks pra nikah' dalam Jurnal Window Of Health, 1.3, (2018), hlm 204-214

${ }^{6}$ Sumarlin Adam, 'Dampak Narkotika Pada Psikologi dan Kesehatan Masyarakat' Jurnal Health and Sport, 5.2, (2012), hlm 15-26

7 Nurdin Bakri, Barmawi, 'Efektifitas Rehabilitasi Pecandu Narkotika Melalui Terapi Islami Di Badan Narkotika Nasional Provinsi Aceh' Jurnal Psikoislamedia, 2.1, (2017), hlm 86-94
} 
fisik maupun batin dan memiliki landasan keimanan yang kuat sehingga tidak lagi melakukan penyalahgunaan narkotika dan obat-obatan terlarang.

\section{Pembahasan}

\section{Definisi Narkotika}

Narkotika berasal dari bahasa yunani yaitu narke atau narkam yang berarti terbius sehingga tidak merasakan apa-apa. Narkotika berasal dari perkataan narcotic yang artinya sesuatu yang dapat menghilangkan rasa nyeri dan dapat menimbulkan efek stupor (bengong), bahan-bahan pembius dan obat bius. $^{8}$

Dalam Kamus Besar Bahasa Indonesia narkotika adalah obat untuk menenangkan saraf, menghilangkan rasa sakit, menimbulkan rasa mengantuk, atau merangsang (seperti opium, ganja). ${ }^{9}$

Narkotika adalah zat atau obat yang berasal dari tanaman atau bukan tanaman, baik sintesis maupun semi sintesis, yang dapat menyebabkan penurunan atau perubahan kesadaran, hilangnya rasa, mengurangi sampai menghilangkan rasa nyeri, dan dapat menimbulkan ketergantungan (UU No. 35/2009 tentang Narkotika). ${ }^{10}$

Penyalahgunaan narkotika adalah masalah perilaku sosial, sehingga perlu pemberian informasi atau pengetahuan yang harus didukung oleh upaya pendidikan kepada anak-anak sejak usia dini sehingga dapat mengubah perilaku dan pola pikir anak, selain membimbing anak agar tumbuh menjadi lebih dewasa. ${ }^{11}$

Penyalahgunaan narkotika merupakan perbuatan yang bertentangan dengan peraturan perundang-undangan sebagaimana termaktub dalam pasal 7 UU Narkotika yang menyatakan bahwa narkotika hanya dapat digunakan untuk kepentingan pelayanan kesehatan dan/atau pengembangan ilmu pengetahuan

\footnotetext{
${ }^{8}$ B.A Sitanggang, Pendidikan Pencegahan Penyalahgunaan Narkotika (Jakarta: Karya Utama, 1999), h. 13.

${ }_{9}^{9}$ Departemen Pendidikan Nasional, Kamus Besar Bahasa Indonesia (Jakarta: Balai Pustaka, 1989), h. 270.

10 Badan Narkotika Nasional RI, Narkoba dan Permasalahannya, (Jakarta: Direktorat Diseminasi Informasi, 2017), h. 3.

"l Badan Narkotika Nasional RI, Buku Panduan Pencegahan Penyalahgunaan Narkoba Sejak Dini, (Jakarta: Direktorat Diseminasi Informasi, 2012), h. 4.
} 
teknologi. ${ }^{12}$ Artinya tindakan yang dilakukan diluar tujuan tersebut merupakan suatu bentuk tindak pidana terhadap narkotika.

\section{Faktor Penyebab Penyalahgunaan Narkotika}

Penggunaan narkotika tidak dilakukan secara spontan, akan tetapi ada faktor-faktor yang mendasari hal tersebut. Faktor tersebut dapat berasal dari dalam diri individu maupun dari lingkungan sekitarnya. Menurut Soubar Isman dalam bukunya, faktor mengapa seseorang menggunakan narkoba yaitu: ${ }^{13}$

a. Faktor Individu

1. Biasanya para remaja ingin coba-coba hal yang baru.

2. Kepribadian yang lemah sehingga mudahnya penjahat narkoba untuk membujuknya.

3. Menghilangkan masalah atau stress.

4. Ikut trend atau mode, dibilang kampungan atau tidak trendy bila tidak mengkonsumsi narkoba.

5. Ingin diterima kelompok.

b. Faktor Lingkungan

1. Tinggal dilingkungan gelap narkoba.

2. Sekolah dilingkungan yang rawan narkoba.

3. Bergaul dengan pemakai narkoba.

4. Dorongan kelompok sebaya.

5. Adanya keluarga yang kurang harmonis.

c. Faktor Pendukung Lain

1. Kelihaian sindikat narkoba untuk mengembangkan jaringannya dengan cara pertama diberi gratis. Kedua dijadikan kurir dengan imbalan narkoba, akhirnya ketagihan.

2. Mitos yang berkembang bahwa dengan mengkonsumsi narkoba dapat meningkatkan tenaga.

3. Pengalaman seseorang yang pernah memakai narkoba.

\footnotetext{
${ }^{12}$ Tommy Busnarma, 'Penerapan Sanksi Pidana Denda Terhadap Pelaku Tindak Pidana Penyalahgunaan dan Peredaran Gelap Narkotika di Pengadilan Negeri Padang', Soumatera Law Review, 1.2, (2019). Hlm 172-192

${ }^{13}$ Soubar Usman, Penyalahgunaan Narkoba dan Upaya Penanggulanganya, (Ngegel: Badan Narkotika Provinsi Jawa Timur, 2020), h. 16-19.
} 
Pendapat lain menguraikan penyebab anak melakukan tindak pidana narkotika atau melakukan penyalahgunaan narkotika, dapat diklasifikasikan atas tiga golongan yaitu: ${ }^{14}$

a. Yang ingin mengalami (the experience seekers), yang memperoleh pengalaman baru yang sensasional, bahwa narkoba dapat menimbulkan sensasi yang dapat diketahui dari teman, film, surat kabar. Ia ingin turut mengalami akibat-akibat dari narkotika dengan berbagai alasan antara lain: menghilangkan keruwetan hidup yang dialami; dengan maksud supaya diketahui orang tuanya, agar terkejut, panic dan menaruh perhatian terhadapnya (bagi anak-anak yang kurang mendapat perhatian); untuk menunjukkkan rasa kesetiakawanana; sekedar terdorong rasa ingin tahu mencoba atau meniru, ataupun rasa ingin mengalami bagaimana rasanya akibat dan pengaruh yang akan ditimbulkan oleh narkotika.

b. Yang ingin menjauhi realitas/kenyataan (the oblivion seekers), yang mengalami kegagalan dalam realitas hidupnya, menganggap dirinya akan selalu mengalami tekanan-tekanan yang datang dari kenyataan-kenyataan hidup, mencari pelarian pada dunia khayal dengan menggunakan narkoba. Alasan lain penggunaan narkoba dalam hal ini adalah untuk menghilangkan rasa kesiapan dengan maksud mendapatkan pengalaman-pengalaman emosional, untuk mengisi kekosongan dan merasa bosan karena kesibukan, untuk menghilangkan rasa kekecewaan, kegelisahan dan berbagai kesulitan yang sukar diatasi.

c. Yang ingin merubah kepribadiannya (personality change), yang tidak percaya diri yang merasa dirinya kurang dari yang lain, dan merasa malu atau takut untuk berhubungan dengan yang lain terutama dengan yang berlainan jenis, atau menghadapi sekelompok orang. Mereka beranggapan bahwa rasa takut, malu dan sebagainya dapat dihilangkan oleh narkoba, maka dia merubah kepribadiannya dengan mempergunakan narkoba sebagai alat. Juga alasan dalam hal ini adalah untuk membuktikan keberanian dalam melakukan tindakan-tindakan berbahaya seperti mengebut, berkelahi, untuk mempermudah penyaluran sex, untuk mencari arti dalam hidup menurut si pemakai (dalam keadaan bimbang).

\footnotetext{
${ }^{14}$ Goomgom, M. Ridwan, 'Analisis Faktor-Faktor Penyebab Anak Melakukan Tindak Pidana Narkotika', Jurnal Penelitian Pendidikan Sosial Humaniora, 2.4, (2019), hlm 580-590
} 


\section{Golongan Pembagian Jenis Narkotika}

Narkotika memiliki beberapa jenis yang dibedakan berdasarkan dari tingkat efek ketergantungannya dan juga hasil dari kesepakatan internasional. Adapun di Indonesia, narkotika dibedakan ke dalam 3 golongan, yaitu: ${ }^{15}$

a. Golongan I

Narkotika yang hanya dapat digunakan untuk tujuan pengembangan ilmu pengetahuan dan tidak digunakan dalam terapi, serta mempunyai potensi sangat tinggi mengakibatkan ketergantungan. Contoh: heroin/putaw, ganja, cocain, opium, amfetamin, metamfetamin/shabu, mdma/extacy, dan lain sebagainya.

b. Golongan II

Narkotika yang berkhasiat pengobatan, digunakan sebagai pilihan terakhir dan dapat digunakan dalam terapi dan/atau untuk tujuan pengembangan ilmu pengetahuan serta mempunyai potensi tinggi mengakibatkan ketergantungan. Contoh: morfin, pethidin, metadona, dan lain-lain.

c. Golongan III

Narkotika yang berkhasiat pengobatan dan banyak digunakan dalam terapi dan/atau tujuan pengembangan ilmu pengetahuan serta mempunyai potensi ringan mengakibatkan ketergantungan. Contoh: codein, etil morfin, dan lain-lain.

\section{Dampak Penyalahgunaan Narkotika}

Dampak penyalahgunaan narkotika pada seseorang tergantung pada jenis narkoba yang dipakai, kepribadian pengguna serta situasi dan kondisi pengguna. Secara umum, dampak ketergantungan atau kecanduan narkotika dapat terlihat pada fisik, psikis dan sosial atau lingkungan masyarakat. (Hasni, $2018)^{16}$

\section{Fisik}

Adapun beberapa dampaknya terhadap fisik yaitu sakit kepala, mual-mual dan sesak nafas. Hal ini disebabkan karena penggunaan dosis obat-obatan terlarang tersebut dalam jumlah yang berlebihan. Adapun efek

\footnotetext{
${ }^{15}$ Badan Narkotika Nasional RI, Narkoba dan Permasalahannya....., h. 4-5.

${ }^{16}$ H. Hasni dkk, 'Dampak Penyalahgunaan Narkoba Pada Remaja Di Desa Dongi Kecamatan Pituriawa Kabupaten Sidenreng Rappang', Jurnal Sosialisasi, . 1.6, (2018), hlm 25-35
} 
yang ditimbulkan ketika menggunakan narkotika dalam hal ini jenis sabusabu adalah sakit kepala, mual-mual dan bahkan sesak nafas.

\section{Psikis}

Dampak penyalahgunaan narkotika pada kejiwaan seseorang yaitu tidak bisa tidur, memiliki semangat yang tinggi yang merupakan efek langsung yang dapat dirasakan oleh individu tersebut setelah menggunakan obat-obatan tersebut. Hal ini merupakan pengaruh dari amphetamine yang terdapat pada shabu-shabu, sehingga energi akan meledak-ledak dan memiliki semangat yang tinggi seolah-olah energi yang dimiliki tidak akan pernah ada habisnya.

\section{Lingkungan}

Dampak lingkungan akibat penyalahgunaan narkotika pada individu seperti berdampak terhadap lingkungan keluarga penyalahguna. Keluarga tersebut akan merasa malu besar karena memiliki anggota keluarga yang memakai zat terlarang. Penyalahgunaan narkotika salah satu tindakan yang melanggar hukum sehingga para pengguna narkotika selalu mendapat cemoohan dari masyarakat sekitar. Selain itu pengguna narkotika juga selalu merasa was-was sehingga enggan untuk bermasyarakat atau bergaul dengan orang yang tidak menggunakan narkoba.

Menurut Kandon, penyalahgunaan obat-obat terlarang dapat terlihat pada fisik maupun psikis seseorang, dampak bagi kesehatan dan penyakitpenyakit yang ditimbulkan serta gejala-gejala psikis yang muncul yaitu: (Kandon dkk, 2019$)^{17}$

a. Gangguan pada sistem saraf seperti: kejang-kejang, halusinasi, gangguan kesadaran, kerus akan syaraf tepi.

b. Gangguan pada jantung dan pembuluh darah seperti: infeksi akut otot jantung, gangguan peredaran darah.

c. Gangguan pada kulit seperti: penanahan (abses), alergi, eksim

d. Gangguan pada paru-paru seperti: penekanan fungsi pernapasan, kesukaran bernafas, pengerasan jaringan paru-paru

${ }^{17}$ Febby Ester Fany Kandon dkk, 'Dampak Obat-Obatan Terlarang Dan Upaya Pengawasan Dini Kepada Anak-Anak Sekolah Untuk Kelompok Ibu-Ibu Di Kelurahan Meras Kecamatan Bunaken Manado', Jurnal Pengabdian Multidisiplin, 1.1, (2019), hlm 1-6 
e. Sering sakit kepala, mual-mual dan muntah, suhu tubuh meningkat, pengecilan hati dan sulit tidur

f. Pada kesehatan reproduksi adalah gangguan pada endokrin, seperti: penurunan fungsi hormon reproduksi (estrogen, progesteron, testosteron), serta gangguan fungsi seksual

g. Kesehatan reproduksi pada remaja perempuan antara lain perubahan periode menstruasi, ketidakteraturan menstruasi, dan amenorhoe (tidak haid)

h. Bagi pengguna narkotika melalui jarum suntik, khususnya pemakaian jarum suntik secara bergantian resikonya adalah tertular penyakit seperti hepatitis B, C, dan HIV.

Dari uraian diatas dapat disimpulkan bahwa dampak yang ditimbulkan penyalahgunaan narkotika dapat terlihat pada fisik, psikis dan sosial atau lingkungan masyarakat. Dampak terhadap fisik antara lain sakit kepala, mual-mual, susah tidur, tidak nafsu makan. Dampak terhadap psikis antara lain, memberikan rasa yang melambung tinggi, memberi rasa bahagia, dan sangat percaya diri. Adanya rasa parno, gelisah ketika menggunakan dan susah tidur. Dampak terhadap lingkungan yaitu diasingkan dalam masyarakat, dan susah dalam bergaul di masyarakat. Dari hal tersebut menggambarkan dampak narkotika juga sangat berbahaya bagi kesehatan tubuh manusia.

\section{Pendekatan Psikologis dalam Mengatasi Kecanduan Penyalahgunaan Narkotika}

Psikologi berasal dari bahasa Yunani yaitu psyche yang artinya jiwa dan logos yang artinya ilmu. Secara harfiah dapat dikatakan bahwa psikologi merupakan ilmu yang mengkaji mengenai kejiwaan manusia. Menurut pendapat para ahli, psikologi merupakan ilmu pengetahuan yang mempelajari tingkah laku manusia baik secara individu maupun terhadap lingkungannya. Perilaku manusia yang dipelajari tersebut baik yang tampak maupun yang tidak tampak. $^{18}$

${ }^{18}$ Faridah Hanum, 'Psikologi Layanan Terhadap Pemustaka dan Kualitas Layanan Prima' Jurnal Iqra', 1l.1, (2017), hlm 101-112 
Adapun objek yang menjadi kajian dalam psikologi seperti perilaku, emosi, karakter, kepribadian dan lain sebagainya. Melalui psikologi, individu dapat memahami tentang dirinya sendiri maupun orang lain apakah dalam kondisi ideal ataupun tidak ideal dalam perspektif psikologi. ${ }^{19}$ Ketika mengetahui ada kondisi yang kurang ideal tersebut dapat segera diambil tindakan yang tepat.

Di era perkembangan keilmuan seperti saat ini, integrasi antar berbagai bidang keilmuan merupakan hal yang lumrah terjadi. Hal ini dikarenakan ilmu tidak bersifat statis sehingga dapat berubah mengikuti perkembangan zaman dan dapat dikombinasikan dengan wacana keilmuan lainnya. Salah satu contoh dari integrasi antar keilmuan adalah psikologi dengan studi Islam.

Studi Islam merupakan usaha-usaha untuk mempelajari hal-hal yang berhubungan dengan Islam. Hal-hal yang dikaji tersebut seperti ajaran, sejarah maupun praktik pelaksanaannya dalam kehidupan sehari-hari. ${ }^{20}$ Studi Islam dilakukan untuk mengkaji lebih mendalam mengenai Islam dan juga mencari solusi atas permasalahan yang terjadi saat ini dari sudut pandang Islam. Hal ini mempertegas bahwa Islam memberikan petunjuk bagi umatnya dalam menjalani kehidupan sehari-hari dan memberikan solusi atas permasalahan umat. $^{21}$

Dalam hal integrasi antara studi Islam dan psikologi, menghasilkan pendekatan psikologis dalam studi Islam. Pendekatan psikologis merupakan pendekatan yang dilakukan untuk melihat kondisi kejiwaan dari pribadi yang beragama. Hal yang dapat diteliti dari pendekatan tersebut adalah kondisi jiwa yang berhubungan dengan agama, baik secara pengaruh maupun akibat dari kemampuan berpikir positif. ${ }^{22}$ Pendekatan psikologis memiliki peran dalam meneliti pengaruh agama terhadap perilaku individu yang akan dijabarkan sebagai berikut ${ }^{23}$ :

\footnotetext{
19 Tarmizi, 'Konsep Manusia dalam Psikologi Islam' Jurnal Al-Irrsyad, 7.2, (2017), hlm 28-48

${ }^{20}$ Suparlan, 'Metode dan Pendekatan dalam Kajian Islam' Jurnal Al-Fondatia, 3.1, (2019), hlm 83-90

${ }^{21}$ Amiruddin Z Nur, Nuriati, 'Pengamalan Ajaran Agama Islam Dalam Kehidupan Bermasyarakat' Jurnal AlMau'izhah, l.1, (2018), hlm 1-11

${ }^{22}$ Munawir Haris, 'Pendekatan Psikologi dalam Studi Islam' Jurnal Palita, 2. 1, (2017), hlm 73-89

${ }^{23}$ Amar Ma'ruf, 'Pendekatan Studi Islam dalam Rehabilitasi Penyalahguna Narkoba' Jurnal Tawadhu, 2.19, (2018), hlm 30-49
} 
1. Sikap dan tingkah laku seseorang atas cara kerja dalam diri individu, seperti cara berpikir,bersikap, bereaksi dan bertingkah laku yang tak terpisah dari keyakinannya.

2. Psikologi yang berhubungan dengan keagamaan memusatkan perhatiannya pada perilaku keagamaan

3. Pendekatan psikologis mengkaji sikap dan tingkah laku seseorang yang timbul dari keyakinan yang dianutnya.

Pendekatan psikologis dapat memberi manfaat bagi individu. Adapun manfaat tersebut antara lain ${ }^{24}$ :

a. Tertanamnya ajaran Agama Islam dalam diri

Pendekatan psikologis dalam studi Islam sebagai media untuk penyampaian ajaran Islam sesuai dengan tingkat usia dari penerimanya. Setiap individu yang beragama Islam, memerlukan penguatan iman dan taqwa melalui pemberian materi mengenai keislaman agar dapat menjadikan dirinya menjadi pribadi yang baik. Pengetahuan akan keislaman tersebut dapat memberinya manfaat di masa kini dan di masa yang akan datang. Pendekatan psikologis digunakan dalam menjelaskan keberagaman sehingga individu dapat memiliki kepuasan tersendiri karena semua permasalahan yang ada dalam hidup dapat diselesaikan melalui pendekatan keagamaan.

b. Manusia Menjadi Terarah dalam Hidupnya

Manusia dalam kehidupannya memerlukan petunjuk agar hidupnya dapat memiliki arah dan tujuan yang jelas. Petunjuk tersebut diperoleh melalui ajaran Agama. Agama melalui kitab sucinya telah menjelaskan segala macam perintah dan larangan bagi manusia agar hidupnya menjadi terarah dan tertata dengan baik. Pendekatan psikologis dalam studi Islam juga memiliki peran dalam hal ini untuk memastikan setiap individu yang beragama Islam dapat menerapkan ajaran dalam Islam dan menjadikan individu tersebut memiliki arah dan tujuan dalam hidup sesuai dengan yang dijelaskan dalam Alquran dan Sunnah.

\footnotetext{
${ }^{24}$ Ayep Rosidi, 'Pendekatan Psikologi dalam Studi Islam’ Jurnal Inspirasi, 3.l, (2019), hlm 45-54
} 
c. Memberikan Ketenangan dalam Diri Manusia

Manusia dalam hidupnya seringkali mengalami berbagai problematika yang membuat dirinya menjadi gelisah, takut, dan merasa tidak tenang. Ketika perasaan tersebut hadir dalam diri manusia, maka ia akan sulit untuk menyelesaikan permasalahan yang ada dan menjadi tidak memiliki semangat untuk menjalani hidup. Oleh karenanya perlu peran dari agama dalam membantu individu tersebut dalam mencapai ketenangan dalam dirinya. Melalui pendekatan psikologis dalam studi Islam, kegiatan-kegiatan keagamaan dapat menjadi obat bagi individu agar dapat memiliki perasaan dan jiwa yang tenang, sehingga dapat menyelesaikan masalah dengan baik dan dapat menjalani hidup dengan bahagia.

Pendekatan psikologis dapat diimplementasikan dalam berbagai hal, salah satunya adalah rehabilitasi bagi penyalahguna narkotika. Penyalahguna narkotika secara umum memiliki kondisi jiwa yang kurang baik ditandai dengan bersikap agresif, sering gelisah, dan hilangnya kepercayaan diri dikarenakan efek dari penggunaan obat-obatan terlarang tersebut. ${ }^{25}$ Mereka memerlukan layanan yang dapat membantu mereka untuk kembali pulih dalam hal fisik maupun kondisi psikisnya. Pendekatan psikologis dalam studi Islam dapat berperan dalam kegiatan terapi ini yang diwujudkan dalam kegiatan berikut ${ }^{26}$ :

a) Terapi Sholat

Sholat merupakan salah satu kewajiban yang harus dipenuhi oleh setiap umat Islam, tanpa terkecuali. Sholat wajib dilaksanakan sebanyak 5 kali dalam sehari dan bisa ditambah dengan sholat-sholat sunnah. Gerakan yang ada dalam sholat dapat memberikan efek positif terhadap kesehatan manusia. Selain itu melalui sholat, individu akan memperoleh ketenangan dalam hidup jika dapat dilakukan secara khusyu'

Terapi sholat dapat diimplementasikan dengan membangun kebiasaan baru bagi klien untuk rajin sholat berjamaah, menambah

\footnotetext{
${ }^{25}$ Sumarlin Adam, 'Dampak Narkotika Pada Psikologi dan Kesehatan Masyarakat' Jurnal Health and Sport, 5.2, (2012), hlm 15-26

${ }^{26}$ Misbakhul Khaer, 'Konsep Islam dalam Merehabilitas Pecandu Narkoba' Jurnal Health and Sport, 2.2, (2018), hlm 185-21l
} 
amalan-amalan sholat sunnah dan meningkatkan kekhusyu'an dari klien dalam menjalankan ibadah Sholat agar dirinya menjadi lebih tenang dan tidak lagi bersikap gelisah.

b) Terapi Membaca Alquran

Alquran merupakan petunjuk bagi umat Islam dan didalamnya terkandung ajaran-ajaran serta perintah dan larangan yang harus dipatuhi oleh setiap umat Islam. Dengan membangun kebiasaan untuk rutin membaca Alquran, individu dapat memperoleh ketenangan dalam hidup dan dapat memperoleh pengetahuan baru tentang Islam yang selama ini belum ia dapatkan. Terapi membaca Alquran dapat diterapkan dengan mengajak para klien untuk membaca Alquran dan terapis dapat menyampaikan nilai-nilai kandungan dalam Alquran tersebut sehingga dapat dimaknai dan dihayati oleh klien.

c) Pemberian Tausiyah

Selain kegiatan rutin sholat dan membaca Alquran, kegiatan lain yang dapat dilakukan adalah dengan mengadakan majelis ilmu yang diisi oleh pemberian tausiyah oleh Ustadz/Ustadzah. Kegiatan ini dilakukan dalam rangka untuk menanamkan nilai-nilai keislaman kepada klien, mengajak klien untuk refleksikan diri apa yang terjadi dalam hidupnya saat ini, memberikan penguatan pada psikis klien melalui pendekatan keislaman sehingga klien merasakan adanya perubahan dari sisi sikap, perilaku dan kepercayaan diri menjadi lebih baik dan siap untuk menjadi masyarakat yang baik ketika telah menyelesaikan masa rehabilitasinya tersebut

\section{Kesimpulan}

Narkotika merupakan zat atau obat yang berasal dari tanaman atau bukan tanaman baik sintetis, maupun semi sintetis, yang dapat menyebabkan penurunan atau perubahan kesadaran, hilangnya rasa, mengurangi sampai menghilangkan rasa nyeri, dan dapat menimbulkan ketergantungan. Faktor penyebab penyalahgunaan narkotika yaitu karena faktor individu, faktor lingkungan dan faktor pendukung lain. Dampak dari penyalahgunaan narkoba dapat terlihat dari fisik, psikis dan sosial atau lingkungan masyarakat. Banyak 
dari individu yang memperoleh kesenangan dan ketenagan dengan mengosumsi obat-obat terlarang tersebut. Oleh karena itu pendekatan psikologi dapat diimplementasikan dalam berbagai hal, salah satunya adalah rehabilitas bagi penyalahgunaan narkotika. Penyalahguna narkotika secara umum memiliki kondisi jiwa yang kurang baik ditandai dengan bersikap agresif, sering gelisah, dan hilangnya kepercayaan diri dikarenakan efek dari penggunaan obat-obatan terlarang tersebut. Untuk mengatasi hal tersebut mereka memerlukan layanan yang dapat membantu mereka untuk kembali pulih dalam hal fisik maupun kondisi psikisnya. Pendekatan psikologis dalam studi Islam dapat berperan dalam kegiatan terapi seperti Terapi sholat, Terapi membaca Al-Quran dan pemberian Tausiyah. Dengan adanya pendekatan psikologi dalam rehabilitasi ini, maka diharapkan dapat membentuk kembali pribadi yang sehat baik secara fisik maupun psikis, sehingga mampu mengambil hikmah dan pelajaran agar tidak terulang kembali.

\section{Daftar Pustaka}

Adam Sumarlin, 'Dampak Narkotika Pada Psikologi dan Kesehatan Masyarakat' Jurnal Health and Sport, 5, (2012), hlm 15-26

Badan Narkotika Nasional RI, Narkoba dan Permasalahannya, (Jakarta: Direktorat Diseminasi Informasi, 2017)

Badan Narkotika Nasional RI, Buku Panduan Pencegahan Penyalahgunaan Narkoba Sejak Dini, (Jakarta: Direktorat Diseminasi Informasi, 2012)

Bakri Nurdin, Barmawi, 'Efektifitas Rehabilitasi Pecandu Narkotika Melalui Terapi Islami Di Badan Narkotika Nasional Provinsi Aceh' Jurnal Psikoislamedia, 2, (2017), hlm 86-94

Busnarma Tommy, 'Penerapan Sanksi Pidana Denda Terhadap Pelaku Tindak Pidana Penyalahgunaan dan Peredaran Gelap Narkotika di Pengadilan Negeri Padang', Soumatera Law Review, 1, (2019). Hlm 172-192

Departemen Pendidikan Nasional , Kamus Besar Bahasa Indonesia (Jakarta: Balai Pustaka, 1989), h. 270.

Ester Febby Fany Kandon dkk, 'Dampak Obat-Obatan Terlarang Dan Upaya Pengawasan Dini Kepada Anak-Anak Sekolah Untuk Kelompok Ibu-Ibu Di 
Kelurahan Meras Kecamatan Bunaken Manado', Jurnal Pengabdian Multidisiplin, 1, (2019), hlm 1-6

Goomgom, M. Ridwan, 'Analisis Faktor-Faktor Penyebab Anak Melakukan Tindak Pidana Narkotika', Jurnal Penelitian Pendidikan Sosial Humaniora, 2, (2019), hlm 580-590

Hamim Khairul, 'Kebahagiaan dalam Perspektif Alquran dan Filsafat', Jurnal Tasamuh, 13 , (2016), hlm 127-149.

Hanum Faridah, 'Psikologi Layanan Terhadap Pemustaka dan Kualitas Layanan Prima' Jurnal Iqra', 11, (2017), hlm 101-112

Harbia, 'Dampak Penyalahgunaan Narkotika, Psikotropika dan Zat Adiktif lainnya terhadap seks pra nikah' dalam Jurnal Window Of Health, 1, (2018), hlm 204-214

Haris Munawir, 'Pendekatan Psikologi dalam Studi Islam' Jurnal Palita, 2, (2017), hlm 73-89

Hasni. H dkk, 'Dampak Penyalahgunaan Narkoba Pada Remaja Di Desa Dongi Kecamatan Pituriawa Kabupaten Sidenreng Rappang', Jurnal Sosialisasi, 1, (2018), hlm 25-35

Heriani Istiani, 'Upaya Penanggulangan Penyalahgunaan Narkoba Secara Komprehensif’ Jurnal Al- ‘Adl, 6, (2014), hlm 44-59

Khaer Misbakhul, 'Konsep Islam dalam Merehabilitas Pecandu Narkoba' Jurnal Health and Sport, 2, (2018), hlm 185-211

Ma'ruf Amar, 'Pendekatan Studi Islam dalam Rehabilitasi Penyalahguna Narkoba’ Jurnal Tawadhu, 2, (2018), hlm 30-49

Nur Amiruddin Z, Nuriati, 'Pengamalan Ajaran Agama Islam Dalam Kehidupan Bermasyarakat' Jurnal Al-Mau'izhah, 1, (2018), hlm 1-11

Rosidi Ayep, 'Pendekatan Psikologi dalam Studi Islam' Jurnal Inspirasi, 3, (2019), hlm 45-54

Rusmalena, dkk, 'Persepsi Masyarakat Terhadap Pengguna Narkoba di Tanjung Pinang Kota’ Jurnal Sosiologis, 6, (2014), hlm.1-13

Sitanggang B.A, Pendidikan Pencegahan Penyalahgunaan Narkotika (Jakarta: Karya Utama, 1999), h. 13.

Suparlan, 'Metode dan Pendekatan dalam Kajian Islam' Jurnal Al-Fondatia, 3, (2019), hlm 83-90 
Jurnal Keislaman, Vol. 4, No. 1, Maret

Tarmizi, 'Konsep Manusia dalam Psikologi Islam' Jurnal Al-Irrsyad, 7.2, (2017), hlm 28-48

Usman Soubar, Penyalahgunaan Narkoba dan Upaya Penanggulanganya, (Ngegel: Badan Narkotika Provinsi Jawa Timur, 2020), h. 16-19. 